\title{
Meneliti Islam: Pada Aspek Mana?
}

\author{
Ismail Suardi Wekke \\ Pascasarjana Sekolah Tinggi Agama Islam Negeri (STAIN) Sorong, Papua Barat \\ Pascasarjana Universitas Islam Negeri (UIN) Antasari Banjarmasin, Kalimantan Selatan \\ Email: iswekke@stainsorong.ac.id
}

\section{Assalamu Alaikum Warahmatullahi Wabarakatuh}

Kita kembali ke pertanyaan awal "kajian Islam dimana aspek yang dapat diteliti?". Ini dikaji dalam rangkaian merespon kebingungan mahasiswa pascasarjana yang belum menemukan topik penelitian.

Ketika mengkaji Islam, maka perlu sejak awal diperhatikan. Bagian Islam yang mana yang dapat diteliti?. Pada aspek keislaman, sudah ada norma yang tidak bisa digugat lagi yaitu wahyu yang ada dalam Alquran. Maka, aspek ini kemudian dijabarkan bahwa pada persoalan ilmu pengetahuan, panduannya adalah wahyu (Natsir, 2006).

Selanjutnya Islam bisa disebut dalam dua aspek normativitas dan historisitas (Abdullah, 1999). Sementara menyebut doktrin dan peradaban (Madjid, 1999).

Untuk penelitian, hanya ekspresi beragama yang dapat diteliti (Mudzhar, 1998). Ini untuk menghindari adanya pertentangan yang bisa menimbulkan kegaduhan. Maka, mengkaji Islam dapat dilakukan pada apa yang tampak saja.

Islam sesungguhnya dapat dilihat dalam pelbagai aspek (Nasution, 1974). Termasuk dalam ragam budaya, Islam juga dapat dilihat sebagai bentuk ekspresi. Namun beberapa pembahasan Nasution mendapatkan koreksi Rasjidi (1977), beliau memandang bahwa tulisan Nasution membawa kepada pemahaman yang keliru.

Ketika perguruan tinggi Islam bertransformasi menjadi universitas, maka kajian keislaman didekati dengan integrasi-interkoneksi keilmuan (Abdullah, 2013; Abdullah 2017a; Abdullah 2017b). Termasuk tidak lagi hanya pada diskursus modern (Sabri, Ikhsan, \& Wekke, 2017).

Sementara itu, Pendidikan tinggi Islam tidak lagi berada di ranah yang sama tetapi ada pengaruh dari pelbagai bidang kehidupan. Maka, saatnya merumuskan kajian keislaman dengan lebih luas (Wekke, 2018; Wekke, 2019; Mujahidah \& Wekke, 2019; Wekke, 2016).

Hanya saja aspek kapasitas dan kewilayahan perlu mendapat perhatian (Wekke, Kahar, \& Amri, 2018; Gonibala \& Wekke, 2018; Wekke \& Faishol, 2017). Termasuk respon Pendidikan tinggi Islam yang tidak saja terkait pada persoalan mahdhah semata (Wekke, Rajindra, Pushpalal, Samad, Yani, \& Umam, 2019).

Maka, kajian Islam dengan pendekatan keilmuan merupakan sebuah ranah penelitian yang interdisipliner. Tidak memungkinkan untuk dijelaskan hanya dengan pendekatan monodisiplin semata. Selanjutnya, perlu ditekankan pada aspek kekhasan masing-masing, sehingga penelitian akan lebih komprehensif. Walaupun masing-masing peneliti menyumbang pada aspek tertentu saja.

Demikian, billahi taufiq wal hidayah. Wassalamu alaikum warahmatullahi wabarakatuh. 


\section{Daftar Pustaka}

Abdullah, A. (2017a). Islam as A Cultural Capital in Indonesia and The Malay World: A Convergence of Islamic Studies, Social Sciences and Humanities. Journal of Indonesian Islam, 11(2), 307-328.

Abdullah, M. A. (1999). Normativitas dan Historisitas. Yogyakarta: Pustaka Pelajar.

Abdullah, M. A. (2013). Agama, Ilmu dan Budaya: Paradigma Integrasi-Interkoneksi Keilmuan. Jakarta: Akademi Ilmu Pengetahuan Indonesia.

Abdullah, M. A. (2017b). Islamic Studies in Higher Education in Indonesia: Challenges, Impact and Prospects for the World Community. Al-Jami'ah: Journal of Islamic Studies, 55(2), 391-426.

Gonibala, R., \& Wekke, I. S. (2018). Strategi Dakwah Masyarakat Minoritas Muslim Minahasa. Yogyakarta: Deepublish.

Hermawanto, A., Ashrori, M., \& Wekke, I. S. (2019). Tradisi Keislaman di Perguruan Tinggi. https://doi.org/10.31227/osf.io/29hba.

Madjid, N. (1992). Islam: Doktrin dan Peradaban. Jakarta: Yayasan Wakaf Paramadina.

Mudzhar, A. (1998). Pendekatan Studi Islam: Dalam Teori dan Praktek. Yogyakarta: Pustaka Pelajar.

Mujahidah, M., \& Wekke, I. S. (2019). Transformasi Perguruan Tinggi Keagamaan Islam Indonesia. https://doi.org/10.31227/osf.io/46evm.

Nasution, H. (1974). Islam ditinjau dari berbagai aspeknya. Jakarta: Universitas Indonesia Press.

Natsir, N. F. (2006). Merumuskan Landasan Epistemologi Pengintegrasian Ilmu Quraniyyah dan Kawniyyah dalam Pandangan Keilmuan UIN, Wahyu Memandu Ilmu. Bandung: Universitas Islam Sunan Gunung Djati.

Rasjidi, M. (1977). Koreksi terhadap Dr. Harun Nasution tentang" Islam ditinjau dari berbagai aspeknya". Jakarta: Bulan Bintang.

Sabri, M., Ikhsan, M., \& Wekke, I. S. (2017). Islam, Keindonesiaan dan Postmodernitas. Malang: Inteligensia Media.

Wekke, I. S. (2016). Learning and Service Quality in Islamic Higher Education of Minority Muslim Bali. International Conference on Ethics in Governance (ICONEG 2016). Atlantis Press.

Wekke, I. S. (2018). Masa Depan Kajian Islam di Indonesia. https://doi.org/10.31227/osf.io/36tua.

Wekke, I. S. (2019). Dinamika Perguruan Tinggi Islam dan Tantangan Masa Depan. https://doi.org/10.31227/osf.io/dv9fx.

Wekke, I. S., \& Faishol, F. (2017). Aplikasi Dan Prinsip Belajar Dalam Pembelajaran Bahasa Arab Perguruan Tinggi Minoritas Muslim. https://doi.org/10.31227/osf.io/ph78g.

Wekke, I. S., Kahar, M. S., \& Amri, I. (2018). Perguruan Tinggi Tanah Papua dan Strategi Pengembangan Pendidikan Tinggi. https://doi.org/10.31227/osf.io/m3kvb.

Wekke, I. S., Rajindra, R., Pushpalal, D., Samad, M. A., Yani, A., \& Umam, R. (2019). Educational Institution on Responding Disasters in Palu of Indonesia. https://doi.org/10.31227/osf.io/drc8q. 